\title{
日本風工学会賞（論文賞）を受賞して
}

\section{寺崎 浩*}

Hiroshi TERAZAKI

この度は, 日本風工学会賞 (論文賞) を頂き, 大変光栄 に存じます。ご推挙頂いた先生ならびにご選考いただき ました委員の皆様に厚く御礼申し上げます。

今回, 受賞対象となりました論文「高層建物の帳壁緊結 部疲労損傷評価用風外力の検討」は, 日本建築学会の構 造系論文集に投稿した論文です。

本研究は, 従来あまり検討されてこなかった高層建物の 外装材の風に対する疲労設計一のアプローチとして, 外 装材に作用する風力特性を, 検討部材に蓄積する疲労損 傷率という観点から検討し, 通常の風圧実験で得られる 統計值を用いて, 風向・風速の変化に対応した疲労損傷 率を算定する近似式を提案したものです。

本研究におきまして親身なご指導を賜りました東北大 学の植松康教授に, この場をお借りしまして厚く御礼申 し上げます。また, 本論文の基となる風洞実験を精力的 に実施していただいた，大成建設技術センター中村良平 氏に厚く御礼申し上げます。

本論文では, 検討対象部位として高層建物帳壁の下地部 材中で設計上最も応力的に厳しい帳壁緊結部のボルトを 選定し, 変動風圧実験に基づく風外力でボルトに発生す る応力時刻歴から, レインフロー法により抽出した応力 振幅レベルとその発生回数に基づいた疲労損傷率をマイ ナ一則に基づいて算定しました。疲労損傷率の算定には 風外力の特徴である平均成分についても, 修正 Goodman 法を用いることにより考慮しています。これらの疲労損 傷率は建物の帳壁内で分布を持ちますが，帳壁中で疲労 損傷率が大きくなる部位を 3 点選定し, その発生風向を も考慮しました。この 3 点についてレインフロー法によ り抽出した応力振幅レベルとその発生回数に着目したと ころ, 数ある応力振幅のうち, 疲労損傷率に寄与寸る割
合が高いのは大きな振幅レベルが支配的であり，この大 きな振幅の発生回数は, 角柱に作用寸る風速とストロ八 ル数にほぼ対応していることが分かりました。また, 風 外力の平均成分が疲労損傷率に与える影響が非常に大き いことも，正負を反転した応力時刻歴の検討により分り ました。

以上に基づき, 10 分間の間に疲労検討部材に発生する 応力振幅とその発生回数並びに, 平均成分の影響を考慮 $し て$, 全風向中に発生する疲労損傷率を近似する実験式 と実験值に基づく算定用係数を提案しました。

疲労損傷率の風向変化については, 外圧係数の変動值の 風向変化と高い相関があることを利用した算定式を提案 し, 風速の変化についても近似式と係数を提案しました。 以上の近似式の展開では，平均值の影響が大きく，これ らの影響を考慮するために，各近似式には実験結果に基 づく係数を与えることにしました。風洞実験で得られた 時刻歴データに基づく検討方法とほぼ同等な疲労損傷率 の算定を比較的簡易な方法で評価できるようにしたつも りですが，結果的に多少複雑なものになってしまいまし た。

最後になりますが, 今回の疲労検討対象とした部材は鋼 製のボルトでしたが，一般的な外装材やその下地部分に は様々な材質が使われています。これらの疲労評価には 材質や部材に対応した疲労特性が必要となりますが, 現 状では十分なデータがないため, 今後のデータの蓄積が 待たれます。

この度の受賞を励みに, 研究を通じて社会に貢献できる よう, より一層研究に精進したいと思っております。こ れからも日本風工学会の皆様にはご指導ご鞭撻の程, よ ろしくお願い申し上げます。 